Vol 14, Issue 7, 2021

\title{
PHYTOCHEMICAL AND ANTIBACTERIAL ACTIVITY OF HEXANE AND ETHYL ACETATE EXTRACT OF KNOXIA SUMATRENSIS (RETZ.) DC.
}

\author{
LOGANATHAN S, SELVAM K* \\ Department of Botany, School of Life Sciences, Periyar University, Salem, Tamil Nadu, India. Email: selsarat@yahoo.com
}

Received: 20 September 2021, Revised and Accepted: 05 May 2021

ABSTRACT

Objective: The study was carried out the phytochemical and antibacterial activity of Knoxia sumatrensis (Retz.) Dc. using hexane and ethyl acetate extracts.

Methods: The phytochemical screening was extracted from hexane and ethyl acetate solvent and its screening was analyzed by standard procedure. GC-MS technique was analyzed in ethyl acetate extract to identify the components present in the extract. The hexane and ethyl acetate extract of the plant was tested for antibacterial activity against human pathogenic bacteria using disk diffusion method.

Results: The phytochemical screening was revealed the presence of phenols, saponins, flavonoids, cardiac glycosides, steroids, and tannins. The GC-MS results showed that the presence of seven bioactive compounds in ethyl acetate extract. The major compounds were identified such as N-Hexadecanoic Acid (9.336), 2-Piperidinone, N-[4-Bromo-N-Butyl] - (37. 883). The ethyl acetate extract showed good antibacterial activity. The maximum zone of inhibition was noticed in $S$. aureus $(8.25 \mathrm{~mm})$ using ethyl acetate extracts at $50 \mu \mathrm{g}$.

Conclusion: Thus, this study the information regarding the phytochemical constituents present in the both extract. Hence, it can be used for further therapeutic applications in the near future study.

Keywords: Phytochemical, Ethyl acetate, Disk diffusion method, Staphylococcus aureus.

(C) 2021 The Authors. Published by Innovare Academic Sciences Pvt Ltd. This is an open access article under the CC BY license (http://creativecommons.org/ licenses/by/4.0/) DOI: http://dx.doi.org/10.22159/ajpcr.2021v14i1.39750. Journal homepage: https://innovareacademics.in/journals/index.php/ajpcr

\section{INTRODUCTION}

Plants are producing large amount of secondary metabolites which have been used for a therapeutic applications. The role of plants in medicinal production is two-fold and served as a natural drawing for the development of new drugs. Medicinal plants represent a rich source of antimicrobial agents [1]. Their capabilities serve as a possible source for the application of wet finishes on the textiles to treat skin, wounds, antifungal, and antimicrobial [2]. Medicinal plants would be the greatest source to obtain a variety of medicines, according to the World Health Organization (WHO), and $80 \%$ of the world's population depends on traditional medicine and a large part of traditional therapies requires the use of plant extracts or their active constituents. [3].

In bacterial diseases stay leading causes of death worldwide [4]. Bacterial standard medication can diminish the degree of death among irresistible patients. However, several cases the growing prevalence of strains from resistance to easily obtainable and inexpensive antimicrobials from bacterial pathogens is harmful in eroding the impact [5]. The defeating of issues thusly required the creation of the new antibacterial specialist. Therapeutic plants are the best way to deal with the bacterial disease.

Knoxia sumatrensis (Retz). DC. belongs to the family Rubiaceae. Around seven species are occur in the Indo-Malayan area in addition two species in Africa [6]. It is profound in deep forest, hills and moist places among the circar Mountains K. sumatrensis leaf paste to apply for affected places of wounds healing [7]. The objective the study, phytochemical, GC-MS, and antibacterial activities of hexane and ethyl acetate extract using K. sumatrensis leaves.

\section{METHODS}

\section{Plant collection}

Knoxia sumatrensis (Retz). DC. Plant was collected in September 2018 from vathalmalai hills $(12.0464 \mathrm{~N}, 78.2220 \mathrm{E})$ which is located in Dharmapuri district, Tamil Nadu, India (Fig. 1). The collected plant was authenticated by Botanical Survey of India (BSI), Coimbatore, Tamil Nadu, India, and the specimen voucher number (BSI/SRC/4/23/2018/ Tech/620).

\section{Extraction}

Plant leaves were shade dried for 2 weeks at room temperature. The dried leaves were grounded using steel blender. The powdered sample was extracting using Soxhlet extraction. Further, the concentrated extracts were evaporated using rotary evaporator. Final extracts were well-preserved in airtight bottle and used for further analysis.

\section{Phytochemical screening}

The qualitative phytochemical screening is described earlier [8]. Dragendorff's tests used for alkaloids, lead acetate used for flavonoids, foam test used for saponins, Ferric chloride test used for tannins, Salkowski test used for terpenoids and steroids, Keller-Kiliani test used for cardiac glycosides, Borntrager's test used for anthraquinones, Ferric chloride test used for tannin and phenol as well as Biuret test used for protein.

\section{Gas chromatography mass spectrophotometry (GC-MS)}

GC-MS analysis of the ethyl acetate of Knoxia sumatrensis was performed using Perkin Elmer GC-MS model. The Clarus 680 GC used in analysis of a fused silica column, packed with Elite-5MS (5\% biphenyl 95\% dimethylpolysiloxane, $30 \mathrm{~m} \times 0.25 \mathrm{~mm}$ ID $\times 250 \mu \mathrm{mdf}$ ) and the components were separated using Helium as transporter gas 
at a constant flow of $1 \mathrm{~mL} / \mathrm{min}$. The temperature of injector was set $260^{\circ} \mathrm{C}$ in the chromatographic run. Sample $1 \mu \mathrm{L}$ was injected in to the instrument at the oven temperature $60^{\circ} \mathrm{C}(2 \mathrm{~min})$; after that $300^{\circ} \mathrm{C}$ at

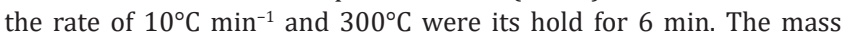
detector temperature $240^{\circ} \mathrm{C}$, ion source temperature $240^{\circ} \mathrm{C}$, ionization mode electron impact $70 \mathrm{eV}$, a scan time $0.2 \mathrm{~s}$, and scan interval $0.1 \mathrm{~s}$. The characterizations of compounds were compared with the database

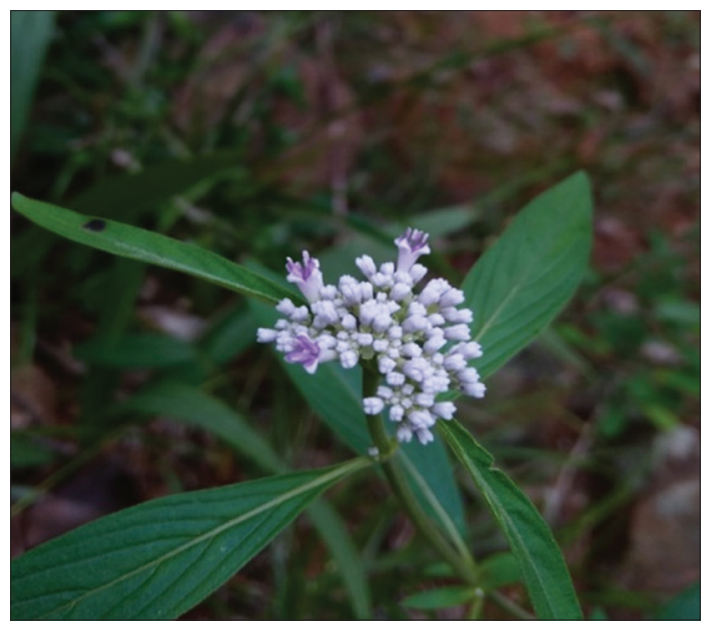

Fig. 1: Knoxia sumatrensis (Retz.) DC of spectrum of known components stored in the GC-MS NIST (National Institute of Standard Technology) library using Turbo mass software (5.4.0).

\section{Antibacterial activity}

Collection of microbes

The bacterial strains were used throughout the investigation namely; Staphylococcus aureus and Escherichia coli were obtained from Department of Microbiology, Periyar University, Salem.

\section{Disk diffusion method}

A total of two microbial pathogens, namely., Staphylococcus aureus and Escherichia coli were tested using of Knoxia sumatrensis leaves extract. In this study, we performed by Bauer et al., [9] disk diffusion method. Nutrient broth was used to culture bacteria as well as fresh overnight culture of inoculums. The test cultures were swabbed on nutrient agar (NA) Plates and permissible to dry for $10 \mathrm{~min}$. A total of two concentrations used like as ( $25 \mu \mathrm{g}$ and $50 \mu \mathrm{g}$ ). DMSO and chloraphenicol were used as negative as well as positive controls (30 $\mu \mathrm{g} / \mathrm{disc})$. The culture plates were incubated for $12 \mathrm{~h}$ in an incubator at $37^{\circ} \mathrm{C}$. The diameters of the inhibition zones were measured in millimeters $(\mathrm{mm})$.

\section{RESULTS AND DISCUSSION}

Phytochemical screening

The phytochemical screenings is represented in Table 1. The presence of phytoconstituents includes flavonoids, saponins, tannins, steroids,

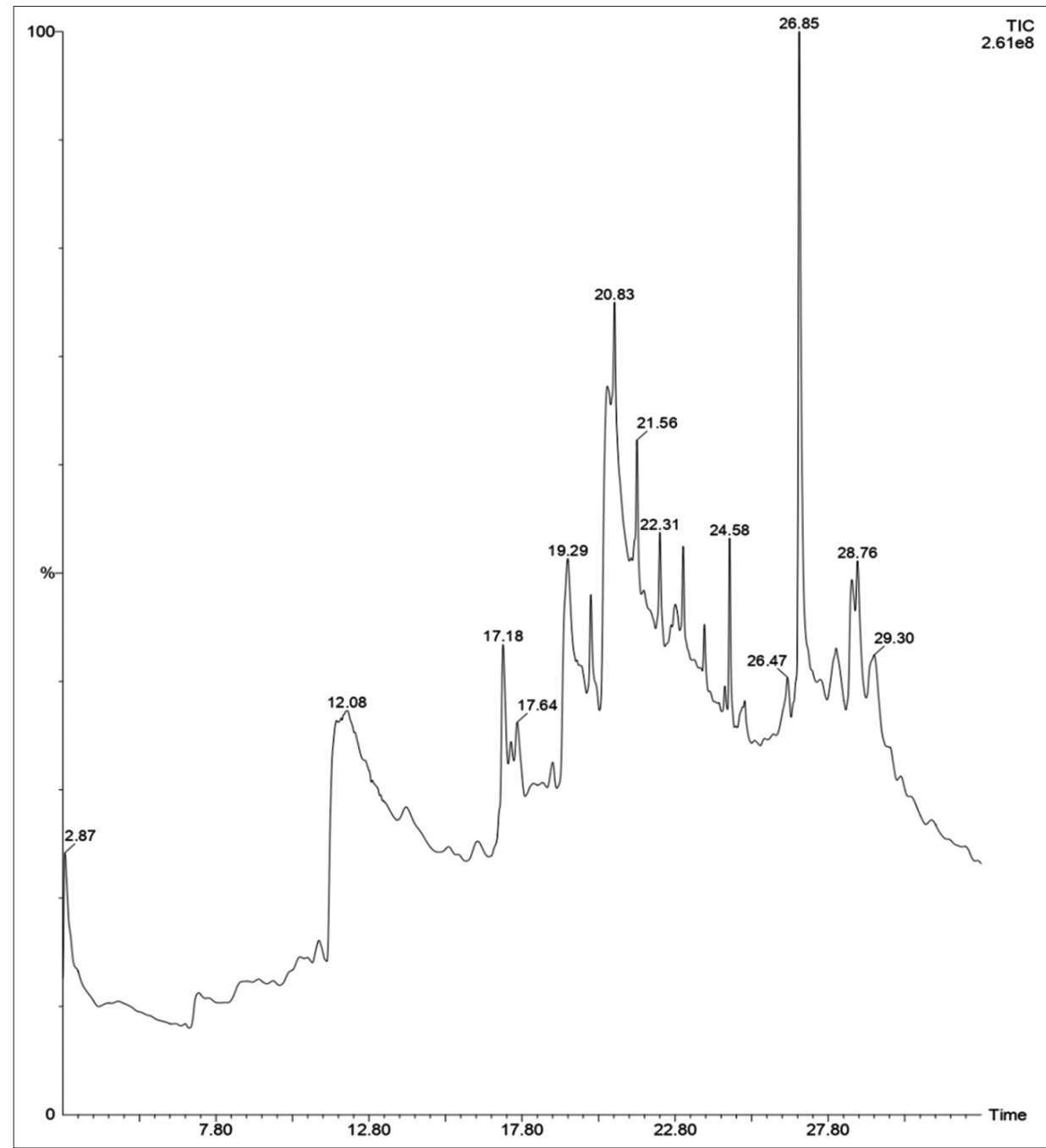

Fig. 2: GC-MS chromatogram of $K$. sumatrensis ethyl acetate leaf extract 
cardiac glycosides, and phenol. Alkaloids, anthraquinones, terpenoids, and protein were absent in both extracts. In, Similar ethyl acetate extract were finding in Myristica dactyloids fruit were presence of the steroids, proteins, carbohydrates, cardio glycosides, and saponins [10]. In earlier findings, Tiliacora racemosa different solvent extract showed that the presence of various secondary metabolites [11].

\section{GC-MS analysis}

Chromatogram is shown in Fig. 2. A total of seven bioactive compounds were present in the ethyl acetate extract of $K$. sumatrensis (Table 2). Nair and Gangprasad [12] were reported that the Gynochthodes ridsdalei

Table 1: Phytochemical screening of $K$. sumatrensis leaves extracts

\begin{tabular}{llll}
\hline S. No. & $\begin{array}{l}\text { Phytochemical } \\
\text { constituents }\end{array}$ & Hexane extract & Ethyl acetate extract \\
\hline 1. & Alkaloids & - & - \\
2. & Flavonoids & + & + \\
3. & Saponins & - & + \\
4. & Tannins & - & + \\
5. & Steroids & + & + \\
6. & Cardiac glycosides & + & + \\
7. & Anthraquinones & - & - \\
8. & Phenol & - & + \\
9. & Terpenoids & - & - \\
10. & Protein & - & - \\
\hline +: Present, -: Absent &
\end{tabular}

Table 2: Bioactive compounds identified from GC-MS analysis of $K$. sumatrensis ethyl acetate leaf extract

\begin{tabular}{|c|c|c|c|c|c|c|c|}
\hline S. No. & $R / T$ & $\begin{array}{l}\text { Peak } \\
\text { area \% }\end{array}$ & Name of the compound & $\begin{array}{l}\text { Molecular } \\
\text { formula }\end{array}$ & $\begin{array}{l}\text { Molecular } \\
\text { weight (M/W) }\end{array}$ & Compound structure & Biological activity \\
\hline 1. & 17.184 & 4.101 & $\begin{array}{l}\text { 3,7,11,15-TETRAMETHYL- } \\
\text { 2-HEXADECEN-1-OL }\end{array}$ & 296 & $\mathrm{C}_{20} \mathrm{H}_{40} \mathrm{O}$ & & \\
\hline 2. & 17.639 & 2.470 & $\begin{array}{l}\text { 3-PIPERIDINOL, } \\
\text { 1,4-DIMETHYL-, TRANS }\end{array}$ & 129 & $\mathrm{C}_{7} \mathrm{H}_{15} \mathrm{ON}$ & & \\
\hline 3. & 19.290 & 9.336 & N-HEXADECANOIC ACID & 256 & $\mathrm{C}_{16} \mathrm{H}_{32} \mathrm{O}_{2}$ & & $\begin{array}{l}\text { Antibacterial and properties } \\
\text { (Tyagi and Agarwal, 2017) }\end{array}$ \\
\hline 4. & 20.831 & 37.883 & $\begin{array}{l}\text { 2-PIPERIDINONE, N-[4- } \\
\text { BROMO-N-BUTYL]- }\end{array}$ & 233 & $\mathrm{C}_{9} \mathrm{H}_{16} \mathrm{ONBr}$ & & $\begin{array}{l}\text { Antimicrobial activity (Al- } \\
\text { Salman et al., 2019) }\end{array}$ \\
\hline 5. & 21.551 & 7.012 & $\begin{array}{l}\text { 7-METHYL-Z- } \\
\text { TETRADECEN-1-OL } \\
\text { ACETATE }\end{array}$ & 268 & $\mathrm{C}_{17} \mathrm{H}_{32} \mathrm{O}_{2}$ & & \\
\hline 6. & 22.301 & 3.385 & HEXATRIACONTAN & 506 & $\mathrm{C}_{36} \mathrm{H}_{4}$ & & $\begin{array}{l}\text { Rsdical scavenger (Arora } \\
\text { and Meena, 2017) }\end{array}$ \\
\hline 7. & 26.848 & 15.211 & VITAMIN E & 430 & $\mathrm{C}_{29} \mathrm{H}_{50} \mathrm{O}_{2}$ & & $\begin{array}{l}\text { Antibacterial, Antioxidant } \\
\text { and Anticancer (Arora and } \\
\text { Meena, 2017). }\end{array}$ \\
\hline
\end{tabular}

Table 3: Antibacterial activity of hexane leaf extracts of $K$. sumatrensis.

\begin{tabular}{|c|c|c|c|c|}
\hline \multirow[t]{3}{*}{ Microorganisms } & \multicolumn{4}{|l|}{ Zone of inhibition (mm) } \\
\hline & \multirow[t]{2}{*}{ Positive control (chloramphenicol) } & \multirow[t]{2}{*}{ Negative control (DMSO) } & \multicolumn{2}{|c|}{ Hexane extracts } \\
\hline & & & $25(\mu \mathrm{g} / \mathrm{ml})$ & $50(\mu \mathrm{g} / \mathrm{ml})$ \\
\hline S. aureus & $23.5 \pm 0.7$ & $00.0 \pm 0.00$ & $00.0 \pm 0.00$ & $7.5 \pm 0.2$ \\
\hline E. coli & $23.25 \pm 0.4$ & $00.0 \pm 0.00$ & $00.0 \pm 0.00$ & $7.25 \pm 0.5$ \\
\hline
\end{tabular}

stem extract revealed the presence of 52 bioactive components. In the previous study on Lactuca runcinata ethanolic leaf extract showed that 20 bioactive compounds were present using in GC-MS [13]. In this study, the major compounds are present in the ethyl acetate extract and are showed that the N-Hexadecanoic Acid (9.336\%), 2-Piperidinone, N-[4-Bromo-N-Butyl]- (37. 883\%), 7-Methyl-Z-Tetradecen-1-Ol Acetate (7.012\%), and Vitamin E (15.211\%). The compound of N-Hexadecanoic acid and Vitamin E has been noticed in plant extract exhibited in antioxidant and antibacterial activity [14,15]. Al-Salman et al. [16] were reported that the compound of 2-Piperidinone, N-[4-Bromo-NButyl]-showed the strong antimicrobial activity. The pharmacological activities of other compounds of ethyl acetate of Knoxia sumatrensis are yet to be determined. Therefore, we assume that the strong biological activities exhibited by Knoxia sumatrensis. In this study are correlated to the occurrence of these bioactive compounds in the ethyl acetate extract. Further, the study, on the isolation of these compounds is needed to confirm their potential benefits.

\section{Antibacterial activity}

The result of the antibacterial activity of $K$. sumatrensis hexane and ethyl acetate extracts is represented in Tables 3 and 4 . The hexane and ethyl acetate extract of $K$. sumatrensis was confirmed the antibacterial activity against $S$. aureus and E. coli (Figs. 3 and 4). The result of the agar disk diffusion method showed the high efficient antibacterial activity against $S$. aureus $(8.25 \mathrm{~mm})$, followed by E. coli $(7.25 \mathrm{~mm})$. The Carica pubescens ethyl acetate fraction showed significant activity against $S$. aureus, E. coli, and S. flexnery [17]. In this study, ethyl acetate extracts showed maximum zone inhibition when compare to hexane

Value are given as Data (Mean \pm SD) $(n=3)$ represent the zone of bacterial growth inhibition $(\mathrm{mm})$ 
Table 4: Antibacterial activity of ethyl acetate leaf extracts of $K$. sumatrensis.

\begin{tabular}{|c|c|c|c|c|}
\hline \multirow[t]{3}{*}{ Microorganisms } & \multicolumn{4}{|l|}{ Zone of inhibition (mm) } \\
\hline & \multirow[t]{2}{*}{ Positive control (chloramphenicol) } & \multirow[t]{2}{*}{ Negative control (DMSO) } & \multicolumn{2}{|c|}{ Ethyl acetate extracts } \\
\hline & & & $25(\mu \mathrm{g} / \mathrm{ml})$ & $50(\mu \mathrm{g} / \mathrm{ml})$ \\
\hline S. aureus & $26.5 \pm 0.5$ & $00.0 \pm 0.00$ & $7.5 \pm 0.1$ & $8.25 \pm 0.3$ \\
\hline E. coli & $22.5 \pm 0.6$ & $00.0 \pm 0.00$ & $00.0 \pm 0.00$ & $7.00 \pm 0.02$ \\
\hline
\end{tabular}
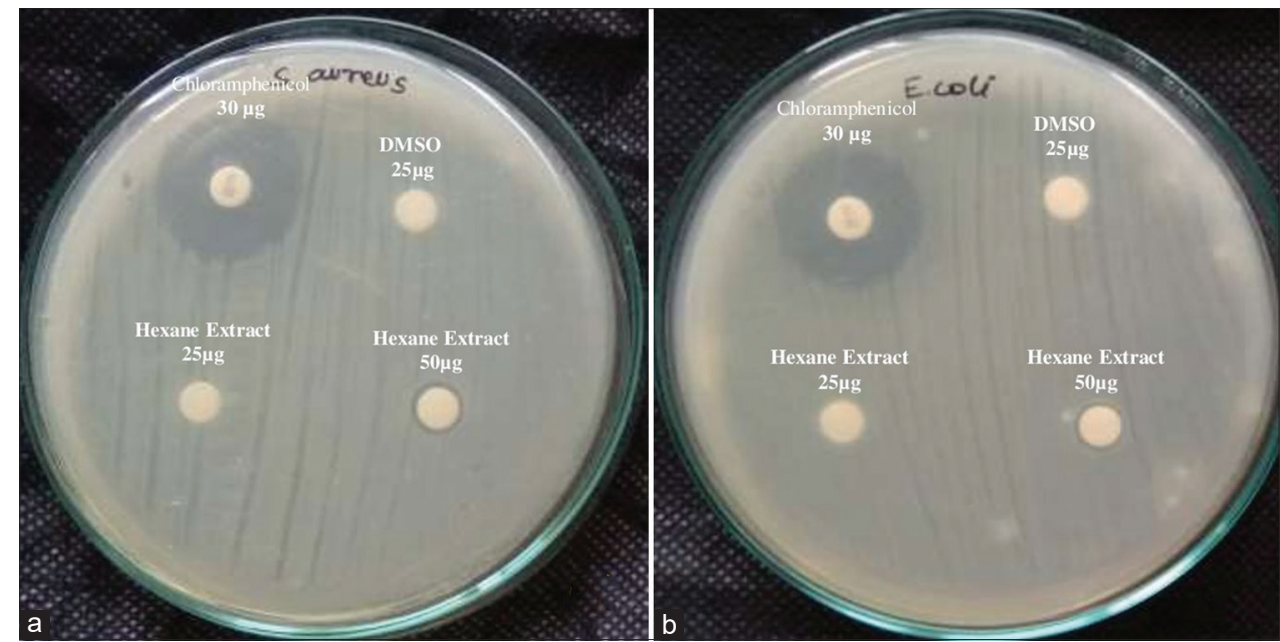

Fig. 3: Antibacterial activity of $K$. sumatrensis hexane leaf extracts against (a) S. aureus and (b) E. coli


Fig. 4: Antibacterial activity of $K$. sumatrensis ethyl acetate extracts against (a) S. aureus and (b) E. coli

extract. Anita et al. [18] were studied the ethanolic tissue extract of Purpura bufo exhibited the maximum zone inhibition against $S$. aureus. Chimahali et al. [19] were reported that the maximum zone inhibition when observed by $S$. aureus $(19 \mathrm{~mm})$ using ethyl acetate tuber extract of Gloriosa superba. In earlier findings, the ethyl acetate extract of Marselia minuta was showed the more active toward S. aureus and $P$. aeruginosa [20]. In ealier study, Soni and Dahiya [21] were reported that the maximum zone of inhibition was noticed in $S$. aureus 1 using Vetiveria zizanoides ethanol extract. The present study, the zone of inhibition was increase when increasing the concentrations of both extracts of $K$. sumatrensis.

\section{CONCLUSION}

The plant $K$. sumatrensis exhibited the presence of large amount of phytoconstituents. The GC-MS study showed that seven bioactive compounds and antibacterial study revealed that the significant activity against $S$. aureus using hexane and ethyl acetate extract at $50 \mu \mathrm{g}$. These investigations potentially recommend the possibility of the plant as an essential source of antibacterial drug may be development pharmaceutical industry.

\section{ACKNOWLEDGMENT}

The authors acknowledge to Periyar University, Salem to providing University Research Fellowship (Ref. No. PU/AD-3/URF/2016). The authors also thank to the Department of Botany, School of Life Sciences, Periyar University, Salem - 636 011, Tamil Nadu, India.

\section{AUTHOR'S CONTRIBUTIONS}

SL Lab related work to bioassay test, preparation of the plant extract. SL and KS data analysis. The experimental work designed and manuscript corrected KS. All authors read and approved the final manuscript. 


\section{CONFLICT OF INTEREST}

The author's declared that they have no conflicts of interest in publishing this research article.

\section{AUTHOR'S FUNDING}

This work is completely self-funded.

\section{REFERENCES}

1. Awaad AS, Zain ME, Al Othman MR, Al-Dosary SK. Phytochemical analysis and antimicrobial activity of medicinal plants against pathogenic microorganisms. Life Sci J 2014;11:350-4.

2. Abidullah S. Phytochemistry and antibacterial activities of some selected plants of war affected area of Bajaur agency, Pakistan. J Pharmacogn Phytochem 2018;7:415-22.

3. Babel S, Guptha R, Sachihar L. Phytochemical analysis of plant resourses having antimicrobial properties obtained from Aravalli hills of Rajasthan, India. Int J Curr Microb App Sci 2018;7:1121-5.

4. World Health Organization. Antimicrobial Resistance. Geneva: World Health Organization; 2017. Available from: http://www.who.int/ mediacentre/factsheets/fs 194/en. [Last accessed on 2017 Apr 24].

5. World Health Organization. Antimicrobial Resistance from WHO. World Health Organization. WHO Model Prescribing Information: Drugs Used in Bacterial Infections. Available from: http://www.apps; http://www.who.int/mediacentre/factsheets/fs194/en. [Last accessed on 2017 Apr 24].

6. Mabberley DJ. Mabberley's Plant-book: A Portable Dictionary of Plants, Their Classification and Uses. $4^{\text {th }}$ ed. Cambridge: Cambridge University Press; 2017

7. Vivek K, Rao R. Some interesting indigenous beverages among the tribals of Central India. Indian J Tradit Know 2007;6:141-3.

8. Harborne JB. A Guide to Modern Techniques of Plant Analysis. London, United Kingdom: Chapman and Hall; 1973.

9. Bauer AW. Antibiotic susceptibility testing by a standardized single disc method. Am J Clin Pathol 1996;45:149-58.

10. Raju R, Deepa A, Vanathi P, Vidhya D. Screening for phytochemicals and FTIR analysis of Myristica dactyloids fruit extracts. Int J Pharm Pharm Sci 2017;9:315-8.

11. Yogeshwari C, Kumudha P. Phytochemical evaluation of Tiliacora racemosa colebr using gas chromatography-mass spectrometry. Asian $\mathrm{J}$ Pharm Clin Res 2018;11:350-3.

12. Renji Nair R, Gangaprasad A. GC-MS analysis of methanolic stem extract of Gynochthodes Ridsdalei, Razafim and B. Bremer, an endemic, endangered medicinal plant of Southern Western Ghats. Int J Curr Pharm Res 2017;9:98-101.

13. Devi JA, Muthu AK. Gas chromatography-mass spectrometry analysis of phytocomponents in the ethanolic extract from whole plant of lactuca runcinata dc. Gas 2015;8:202-6.

14. Tyagi T, Agarwal M. Phytochemical screening and GC-MS analysis of bioactive constituents in the ethanolic extract of Pistia stratiotes L. and Eichhornia crassipes (Mart.) solms. J Pharmacogn Phytochem 2017;6:95-206.

15. Arora S, Meena S. GC-MS profiling of Ceropegia bulbosa Roxb. var. bulbosa, an endangered plant from Thar Desert, Rajasthan. J Pharm Innov 2017;6:568-73.

16. Al-Salman HN. Antimicrobial activity of the compound 2-piperidinone, n-[4-bromo-n-butyl]-extracted from pomegranate peels. Asian J Pharm 2019;13:46-53.

17. Sugiyarto, Novalina D, Susilowati A, Sasongko H. Antibacterial activity of ethyl acetate and n-hexane fractions of Carica pubescens rind and seeds. In: AIP Conference Proceedings. Vol. 2019. United States: AIP Publishing LLC; 2018. p. 050005.

18. Anita A, Punitha D, Selvaraj D. Screening of marine gastropods for potential antibacterial substances against pathogenic bacteria. Int J Zool Appl Biosci 2020;5:180-4.

19. Chimahali J, Jebamalar A, Duraikannu G, Thirumal S. Phytochemical analysis and evaluation of antimicrobial activity in the whole plant extracts of Gloriosa superba. Phanel 2019;12:245-9.

20. Bindu AR, Rosemary J, Akhila S. Antimicrobial activity screening of M. minuta extracts. Int J Pharm Pharm Sci 2014;6:581-3.

21. Soni A, Dahiya P. Screening of phytochemicals and antimicrobial potential of extracts of Vetiver zizanoides and Phragmites karka against clinical isolates. Int J App Pharm 2015;7:22-4. 